\title{
Improving Students' Critical Thinking Ability Through Lesson Study Activities
}

\author{
Nelya Eka Susanti*, Yuli Ifana Sari \\ Geography Education Study Program \\ Universitas PGRI Kanjuruhan Malang \\ Malang, Indonesia \\ *Nelyaeka@unikama.ac.id
}

\begin{abstract}
Critical thinking is very important in learning new material and relating it to student's previously-learned material. The study aimed to (1) to improve students' critical thinking skills through the Contextual Teaching and Learning (CTL) approach in Lesson Study activities; (2) identify learning problems in the Environmental Geography course and alternative solutions through the involvement of other lecturers in lesson study activities. This research is a Classroom Action Research which includes two cycles. The procedure used in conducting this research follows the stages of the lesson study, namely the plan, do, and see stages. The results show that: 1) The Contextual Teaching and Learning approach in Lesson Study activities is very suitable to be applied to solve and analyse problems in the surrounding environment; 2) identification of learning problems in the Environmental Geography course so that by giving cases in the Problem Based Learning model and input from other lecturers during Lesson Study can improve students' critical thinking to solve problems.
\end{abstract}

\section{Keywords—critical thinking, CTL, lesson study}

\section{INTRODUCTION}

Critical thinking is very important in learning new material and relating it to students' previously-learned material. The lecturer is expected to be able to develop students' critical thinking skills by providing examples of casuistic problems or constructivist-based learning that requires problem-solving. Over time, the Environmental Geography course began to cover broader matters related to sustainable development. The scope of environmental geography does not only depend on the geographical condition of an environment but has taken part in various fields of life, including research in the field of environmentally sound development.

Contextual is one of the principles of learning that allows students to learn meaningfully from the things they learn related to what is happening in the environment. Contextual Teaching and Learning (CTL) Approach is an approach that helps students understand what they are learning by connecting their subject with their real-life context [1]. Furthermore, outline the teaching techniques associated with CTL as follows: cooperative learning, problem-based learning, work- based learning, project-based learning, service-learning and react strategies. These approaches help the teachers connect the material content with real circumstances, and motivates the learners to relate to the knowledge and application in their lives [2]. CTL strategies are likewise fundamental in emphasizing critical thinking, recognizing the requirement of teaching and learning in a different context, motivating the students to study each other, and employing authentic evaluation [3].

The learning model used in this study is the Snowball Throwing model and the Problem Based Learning model. Snowball Throwing and Problem Based Learning in Lesson Study are focused on improving students' critical thinking skills which are carried out collaboratively by lecturers in lesson study activities. Lesson Study is a learning quality improvement program carried out by lecturers collaboratively, with the main steps of designing learning to achieve goals, implementing learning, observing the implementation of the learning, and reflecting to discuss the learning that is being studied as material for improvement in the next learning plan.

Lesson study is one of the effective solutions to solve learning problems in the Environmental Geography course in the $2015 \mathrm{D}$ class, where only about $50 \%$ of students complete critical thinking skills. Lesson study has been defined as a form of professional development in which teachers come together for some time to improve their lessons by collaboratively designing, implementing, reflecting on, and revising several lesson artefacts [4-6]. The aims of this study were (1) to improve students' critical thinking skills through Contextual Teaching and Learning in Lesson Study activities; (2) to identify learning problems in the Environmental Geography course and alternative solutions through the involvement of other lecturers in lesson study activities.

\section{RESEARCH METHODS}

This research is a Classroom Action Research which includes two cycles. The procedure used in conducting this research follows the stages of the lesson study, namely the plan, do, and see stages $[7,8]$. 
The research subjects were students of the 2015D class of Geography Education Study Program who are currently taking the Environmental Geography Subject. The selection of subjects in this study is based on the consideration that the subject has identified problems during observation and interviews.

The data collected in this study include information data about the condition of students from a qualitative and quantitative aspect. Qualitative aspects are field data about the results of observations, interviews, review of documents or archives that describe classroom learning, constraints during learning, and the learning model used. The quantitative aspect includes solving problems.

Data analysis in this study starts from the beginning of data collection until the end of data collection. This study uses technical data analysis with quantitative descriptions.

\section{RESULTS AND DISCUSSION}

\section{A. Cycle I}

1) Description of the cycle I activities: The implementation of the cycle I activities is focused on deepening material on Environmental Impact Assessment (EIA). In the first cycle, it is planned to use a learning model that can direct students to gain a deeper and more critical understanding of the concept of implementing EIA. In cycle, I, the application of learning was carried out by providing opportunities for each group to formulate things that were not understood, which were then given to other groups. The learning model applied is the Snowball Throwing model.

This Snowball Throwing model can provide opportunities for friends in groups to formulate questions systematically. One of the advantages of the Snowball Throwing learning model is that students are actively involved in the learning process, learning becomes more effective and all three aspects of knowledge, attitudes, and skills can be achieved [9-11].

2) Plan stage: The planning stage in cycle I was carried out on October $27^{\text {th }}, 2017$. This stage began with the preparation of a lesson plan to be implemented. In the lesson plan and chapter design cycle, I focused on deepening the concept of EIA and using the Snowball Throwing learning model to accommodate all student questions. Besides, in planning a structured Student Worksheet (LKM), several steps were developed to be taken by each group, these steps were intended to clarify each group's to-do list and to improve students' activity and critical thinking skills.

3) Do stage: The implementation stage of the cycle I was held on October $30^{\text {th }}, 2017$, from 11:10 to 12:50 Western Indonesia Time. The lecture activities begin with opening lectures, delivering an outline of the material on EIA, followed by delivering the course objectives to be achieved at the day meeting.
After relating the summary of the material that had been studied in the previous week with the outline of today's material, the model lecturer directed students to sit in their respective groups and formulates several questions according to the analysed articles then distribute the questions to other groups.

At the end of the lecture, the model lecturer asked the students to submit their worksheets as a report. The model lecturer then concluded and reinforced the lecture that had taken place that day. Also, the model lecturer asked questions regarding the material that had not been understood in the day's meeting.

4) See stage: The reflection stage of the implementation of the cycle I was carried out after the implementation of the cycle ends. In the reflection stage, the implementation team discusses all the implementation that has been carried out in the Do Stage. Based on observations made by the observer, several findings were found at the Do Stage that had been carried out, including:

- The task of analysing articles increases students' critical thinking skills.

- The results of the final test in cycle I show that the average percentage of students' critical thinking skills who completed their studies in the first cycle was $54.5 \%$ or 6 students, while $45.5 \%$ or 5 students did not complete.

- Explanation from the lecturer after answering questions from other groups was very necessary to strengthen students' material understanding.

\section{B. Cycle II}

1) Description of cycle II activities: The implementation of cycle II activities was focused on improving students abilities to analyze cases related to the Environmental Impact Assessment (EIA) and the Strategic Environmental Assessment (SEA). Cycle II was planned to use a learning model that can direct students to be able to identify problems and be able to explain the role of EIA/SEA in development. In the second cycle, the application of learning was carried out by providing opportunities for each group to analyze different development cases that had been given to each group. Cycle II applied the Problem Based Learning Model.

Problem Based Learning (PBL) has a crucial role for the students in the process of exploring important and meaningful questions, investigating a problem solution, and developing a deep-integrated understanding of content and process [12]. PBL is an instructional method where relevant problems are introduced at the beginning of the instruction cycle and used to provide the context and motivation for the learning that follows. This definition requires active and usually (but not necessarily) collaborative or cooperative conditions. It involves a significant amount of self-directed learning on the part of the students [13]. In brief, PBL is a pedagogical approach that 
enables students to learn while engaging actively with meaningful problems. Students are given the opportunities to problem-solve in a collaborative setting, create mental models for learning, and form self-directed learning habits through practice and reflection [14].

2) Plan stage: The planning stage in cycle II was carried out on October $27^{\text {th }}, 2017$. This stage began with the improvement and preparation of lesson plans that would be carried out based on the reflection of Cycle I. Lesson Plan and Chapter Design cycle II focused on deepening the concept of EIA and SEA by examining development cases in Indonesia. Besides, in planning a structured Student Worksheet (LKM) that was developed containing the steps that must be taken by each group, it was intended to clarify what each group, it was to do and to increase activeness and thinking skills' critical student.

3) Stage do: The implementation phase of cycle II was held on October $31^{\text {st }}$, 2017, from 16:10 to 17:50 Western Indonesia Time. Lecture activities began with opening lectures, delivering an outline of material on EIA and SEA, followed by delivering the course objectives to be achieved at today's meeting.

After relating the summary of the material that had been studied in the previous week with the outline of today's material, the model lecturer directed students to sit in their respective groups and distributed worksheets containing development cases in Indonesia. Each student analysed the case that had been given, identified the problem in the case, analysed the role of EIA and SEA in the case, and identified the student's role in dealing with these problems. The learning was continued with a short presentation from each group.

At the end of the lecture, the model lecturer asked each group to report their worksheets. The model lecturer then concluded and reinforced the activities that had taken place that day. Also, the model lecturer asked regarding the material that had not been understood in the day's meeting

4) See stage: The reflection stage of the implementation of cycle II was carried out after the cycle ended. In the reflection stage, the implementation team discussed all the implementation that had been carried out in the do stage. Based on observations made by the observer, several findings were found at the do stage that had been carried out, including:

- Problem Based Learning model was very suitable to be applied with material related to EIA and SEA (solving and analysing environmental problems).

- Giving cases in Problem Based Learning could improve students' critical thinking to solve problems.

- The results of the final cycle II test showed that the average percentage of students' critical thinking skills who completed their studies in cycle II increased to
$81.8 \%$ or 9 students, while $18.2 \%$ or 2 students did not complete.

- Cultivating characters about loving the environment during learning needs to be inserted during the explanation.

The studies reviewed above suggest that PBL is an effective teaching and learning approach, particularly when it is evaluated for long-term knowledge retention and applications. One gap in earlier studies on the effectiveness of PBL is that the studies tended to focus on medical education. However, there is now an increasing number of experimental studies in other disciplines that provide evidence of the superior performance of students learning in PBL conditions as opposed to lecture conditions $[15,16]$.

The results of the reflection from both cycles show that lesson study can make classroom learning closer for lecturers and students. Lesson study creates multiple "pathways for learning" that lead to instructional improvement. According to her model, teachers' thinking and practice may improve in multiple ways as a result of, 1 . increased knowledge of the subject matter, 2. increased knowledge of instruction, 3 . increased ability to observe students, 4. stronger collegial networks, 5. stronger connection of daily practice to long-term goals, 6. stronger motivation and sense of efficacy, and 7. improved quality of available lesson plans [17].

\section{CONCLUSION}

Based on the implementation of the learning that has been done, it can be concluded that:

- The Contextual Teaching and Learning approach in Lesson Study activities is very suitable to be applied to solve and analyse problems in the surrounding environment.

- The identification of learning problems in the Environmental Geography course so that by giving cases in the Problem Based Learning model and input from other lecturers during lesson study can improve students' critical thinking to solve problems.

\section{ACKNOWLEDGMENT}

This research was supported by Universitas PGRI Kanjuruhan Malang. I would like to thank all those who have supported this research. Thanks to colleagues, the Lesson Study team for their cooperation in supporting the smooth running of this research. Thank you to all students who have been involved in this research.

\section{REFERENCES}

[1] E.B. Johnson, Contextual teaching \& learning: menjadikan kegiatan belajar-mengajar mengasyikkan dan bermakna. MLC, 2007.

[2] R. Berns and P. Erickson, Contextual teaching and learning: Preparing students for the new economy. Highlight Zo. Res., 2001. 
[3] A. Blanchard, Contextual teaching and learning. Educ. Serv., 2001.

[4] J.W. Stigler and J. Hiebert, The teaching gap: Best ideas from the world's teachers for improving education in the classroom. Simon and Schuster, 2009.

[5] A. Takahashi and M. Yoshida, "Lesson-study communities," Teach. Child. Math., vol. 10, no. 9, pp. 436-437, 2004.

[6] C. Fernandez and M. Yoshida, Lesson study: A Japanese approach to improving mathematics teaching and learning. Routledge, 2012.

[7] S. Hendayana, Lesson Study: Suatu Strategi untuk Meningkatkan Keprofesionalan Pendidik. Bandung FPMIPA UPI dan JICA, 2006.

[8] I. Putri, "Lesson study implementation of Indonesian language learning at grade VII.5 MTSN Lubuk Buaya Padang," Komposisi J. Pendidik. Bahasa, Sastra, dan Seni, vol. 15, no. 1, pp. 39-52, 2014.

[9] Y.E. Putri and M. Chatri, "The Effects of Snowball Throwing (ST) Model Aided by Activity Sheets with Nuances of Problem Solving on Student Skills,” Int. J. Progress. Sci. Technol., vol. 15, no. 2, pp. 191194, 2019.

[10] Y. Apsari, "Snowball throwing in teaching grammar," Lingual, vol. 10, no. 1, pp. 52-59, 2018.
[11] H. Susanty, "Use of the snowball throwing technique for teaching better ESL speaking,” English Educ. J., vol. 7, no. 1, pp. 117-129, 2016.

[12] M. Frank, I. Lavy and D. Elata, "Implementing the project-based learning approach in an academic engineering course," Int. J. Technol. Des. Educ., vol. 13, no. 3, pp. 273-288, 2003.

[13] M. Prince, "Does active learning work? A review of the research," Journal of engineering education, vol. 93, no. 3, pp. 223-231, 2004.

[14] E.H. Yew and K. Goh, "Problem-based learning: An overview of its process and impact on learning," Health Professions Education, vol. 2, no. 2, pp. 75-79, 2016.

[15] S.M.M. Loyens, S.H. Jones, J. Mikkers and T. van Gog, "Problem-based learning as a facilitator of conceptual change," Learn. Instr., vol. 38, pp. 34-42, 2015.

[16] M.A. Pease and D. Kuhn, "Experimental analysis of the effective components of problem-based learning," Sci. Educ., vol. 95, no. 1, pp. 57-86, 2011.

[17] C. Lewis, R. Perry, and J. Hurd, "How do teachers learn during lesson study," Build. our Underst. lesson study, pp. 77-84, 2005. 